Љиљана Ж. Никић

Основна школа „Станко Крстин“

Радојево

Мастер професор српске књижевности

и језика

jovanov.ljiljana@gmail.com
UDK 821.163.42.09-13 Gundulić Dž.

DOI: $10.19090 /$ zjik.2019.115-129

стручни научни рад

\title{
ЖЕНСКИ ЛИКОВИ У ОСМАНУ ЏИВА ГУНДУЛИЋА И ЊИХОВА СУДБИНА У МАЖУРАНИЋЕВОЈ ДОПУНИ ${ }^{1}$
}

САЖЕТАК: У раду се анализирају женски ликови у Осману Ивана Гундулића. Пажња је посвећена оним јунакињама које су носиоци радњи романтичних епизода, али и јунакињама које су само споменуте у делу, а које су истовремено познате историји. Посебна пажња посвећена је допуни Ивана Мажуранића и 14. и 15. певању. Циљ овог рада јесте да, применом компаративне методе и критичко-интерпретативног поступка, укаже на међусобну повезаност и сличност између јунакиња романтичних епизода, указујући на значај осталих женских ликова, али и на значај Мажуранићеве допуне у којој су приказане њихове судбине.

Кључне речи: барокна књижевност, женски ликови, Гундулић, Мажуранић, Торквато Тасо.

Иван Гундулић (1589-1638) $)^{2}$ сматра се најважнијим представником барокне књижевности стваране у старом Дубровнику. ${ }^{3}$

${ }^{1}$ Рад је настао као семинарски рад у оквиру курса „Жена у књижевности и култури старог Дубровника“, на докторским студијама на Одсеку за српску књижевност и језик. Менторка је доц. др Невена Варница.

2 У наслову рада наведено је име Џиво. Облик имена Џиво био је уобичајен за властелу (Гундулић 2001:7).

${ }^{3}$ Према речима Злате Бојовић, књижевни рад започео је крајем прве деценије 17. века. Претпоставља се да је писао љубавну поезију од које је познат једино препев три песме италијанског песника Ђиролама Претија са насловом Љубовник срамежљиви. Његово стваралаштво обележиле су и драме, препев покајнички псалама, спев Сузе сина разметнога, пасторала Дубравка. Међутим, Осман је било његово најпознатије дело. 
Водио је порекло из племићке, веома угледне, породице, а носио је и епитет „краља илирске поезије” који је добио након препевавања седам покајничких Давидових псалама. Међутим, оно што је представљало врхунац његовог стваралаштва јесте управо стварање дела Осман, које се сматра најбољим епом словенског барока. Наиме, у бароку је писање епа сматрано књижевним послом највишег реда те је представљало круну литерарног опуса сваког писца. Епско песништво давало је највеће могућности да најпотпуније и на најбољи начин, барокним стилом и изразом, песник пренесе сплет сложених идеја тога времена, те је због тога заузимало изузетно важно место у дубровачкој књижевности (Бојовић 2014: 266). То је сигурно био један од подстицајних разлога који је навео Ивана Гундулића да ствара османа. ${ }^{4}$

Овај историјско-романтични еп остао је недовршен, али је, према речима Злате Бојовић, био познат у време док га је писао, о чему сведоче и дела његових савременика из којих се види да су знали за Османа. ${ }^{5}$ Разлог због којег је ово дело остало недовршено, била је песникова прерана смрт. Тако је оно остало у облику који је одредила песникова судбина - са двадесет певања, али без четрнаестог и петнаестог. ${ }^{6}$ Та певања нарочито су интересантна јер би се у њима,

${ }^{4}$ Плодни аутори су, поред писања епа, круном стваралаштва сматрали и препевавања неког од највећих дела из италијанске књижевности. Поред Османа, не треба изоставити ни Гундулићев религиозно-рефлексивни спев Сузе сина разметнога, јер су подједнако популарни били и епови и спевови.

5 Злата Бојовић у предговору под насловом Иван Гундулић наводи податак да је Осман био познат у време док је стваран, али не наводи савременике којима је овај историјско-романтични еп био познат (Гундулић 2001: 21).

${ }^{6}$ Постоје претпоставке да су ова два певања изгубљена, да их је песник уништио, али најприхваћенија претпоставка је та да нису ни написана. Бранко Летић у предговору Османа наводи да је најрадикалнији теорија Армина Павића да се ради о два засебна епа - Османиди (дело обухвата певања о догађајима у Цариграду) и Владиславиди (дело обухвата певања о словенским земљама и народима). Оваквој се претпоставци, међутим, опире структура дела рађена према владајућој теорији барокног епа (Гундулић 1990: 14). 
вероватно, разрешила судбина женских ликова Крунославе, Соколице и Сунчанице. Овако је еп остављен без два певања, а наведени женски ликови се, од шеснаестог до двадесетог певања, више не спомињу.

Судбину ових јунакиња покушали су да реше песници каснијих времена - један непознати Дубровчанин, Пјерко Соркочевић и Марин Златарић, ${ }^{7}$ који су предвиђали оптимистичко решење. Четврта допуна, коју је испевао Иван Мажуранић а која се разликује од претходних, сматра се најуспелијом и најближа је духу Гундулићевог епа. ${ }^{8}$

С обзиром на то да је фокус у овом раду усмерен на женске ликове у Осману Ивана Гундулића, посебно ће, како смо навели, бити интересантно четрнаесто и петнаесто певање Ивана Мажуранића. Први разлог због ког је ова допуна одабрана као најрепрезентативнија јесте тај што је написана, како је већ горе наведено, у духу Гундулићевог епа. Други разлог је тај што се ова допуна не подудара са допунама

${ }^{7}$ Пјерко Соркочевић и Марин Златарић стварали су на преласку из 18. у 19. век.

8 Злата Бојовић, приликом приређивања Османа, изоставља допуне неког од горе наведених песника. Она, на месту где би требало да буду четрнаесто и петнаесто певање, наводи само песнике који су покушали да употпуне неиспуњени простор и као најуспелију допуну издваја Мажуранићеву (Гундулић 2001:366). Бранко Летић, приликом приређивања Османа, не оставља „празнину” аутентичном делу, већ је употпуњује Мажуранићевом допуном. У предговору приређивача примећује се несагласност (која ствара конфузију) са певањима у делу. Он, наиме, наводи да Осману недостају 13. и 14. певање, а затим додаје 14. и 15. певање, односно допуне. (Гундулић 1990: 14.) Питање да ли делу заправо недостају тринаесто и четрнаесто певање, како се она броје у старим рукописима, или четрнаесто и петнаесто поставља и Мирослав Пантић у предговору Османа наводећи разноврсне теорије тадашњих преписивача које су непоуздане (Гундулић 1967: 12). Милорад Живанчевић такође потврђује мишљење да је Мажуранићева допуна најуспелија, наводећи да је Мажуранић мајсторски решио задатак који је био пред њим. Он наводи и то да је прва верзија допуне Османа још из 1842. године. Тај рукопис, сачуван у фрагментима, објављује под насловом Рукопис Мажуранићеве допуне Османа (Живанчевић 1961: 253). 
Мажуранићевих претходника - анонимног Дубровчанина, Пјерка Соркочевића и Марина Златарића, те тиме постаје и интересантнија. Споменути песници, наиме, пошли су од основе коју је дао Ђанлука Волантић и која предвиђа оптимистичко решење заплета повољног за све јунакиње - и Крунославе, и Соколице, и Сунчанице. Мажуранић, међутим, оптимистичан крај нуди само Сунчаници.

Ми се у овом раду нећемо бавити само ликовима Крунославе, Соколице и Сунчанице, премда су оне међу женским ликовима најистакнутије. Бавићемо се и ликом лепе Аџамкиње Бегум, али и оним женским ликовима који су само споменути или којима је посвећено значајно мање стихова. Разлог је тај што су у овом историјско-романтичном епу неки женски ликови заправо плод песникове маште, узора и тадашње поетике, а неки су заиста познати историји.

Када је реч о стварању овог историјско-романтичног епа, никако не треба изоставити чињеницу да је пресудан утицај на Гундулићево стваралаштво имао Торквато Тасо и дело Ослобођени Јерусалим. Поштујући теоријска правила Торквата Таса, Гундулић је створио еп од двадесет певања. ${ }^{9}$ Према речима Ђулија Феронија, очараност класичним моделима и позивање на оне делове Аристотелове Поетике који се тичу Хомерових епова, подстакле су у 16. веку многе покушаје репродукције класичног епског жанра путем модерних форми. Тасов Ослобођени Јерусалим херојски је еп који је заиста био на висини савременог света, богат витешким елементима. Тасово песничко стваралаштво уско је повезано са његовим критичким и теоријским схватањима. Његова дела увек покушавају да се држе програмских и општих правила. Позивање на класичну структуру и

${ }^{9}$ Иван Гундулић је добро познавао законитости поетике епског песништва које је, у расправама о епском песништву Говори о епској поезији, 1564, и Говори о херојском спеву, 1594, формулисао Торквато Тасо, међутим, није их се у потпуности могао придржавати. Један од одступања од поетике био је Гундулићев избор главног јунака. Уместо Владислава, који је носилац хришћанске врлине, песник узима Османа за јунака, који заправо представља носиоца негативне идеје муслимана (Гундулић 2001: 22). 
оно што о епици каже Аристотел у Поетищи, мора, међутим, према песниковом мишљењу да се усклади са захтевима савремене публике.

Тасо тежи модерном класицизму, ослањајући се на идеје преузете из Аристотелове Поетике и идеје које потичу из реторичке и Платонове традиције. Епска поезија, према његовом мишљењу, треба да се бави најплеменитијим и најузвишенијим поступцима. Због тога прибегава историјским садржајима обогаћеним измишљеним елементима који изгледају истинито. С обзиром на то да је важан циљ поезије и забава, неопходно је спојити и веродостојно са зачудним. Неопходно је, ипак, избећи паганске бајке и непотребне измишљене приче и окренути се „зачудној хришћанској тематици“, која у свести публике постаје веродостојна а истовремено је у стању да забави (Ферони 2005: 376-377).

С обзиром на то да се од песника захтевало да за предмет дела одабере догађај који је достојан епске форме, опредељење Ивана Гундулића за опевање савремених догађаја - Хоћинског боја (16211622) и Османовог убиства - представља одступање од Тасове поетике. $^{10}$

Радњу самог епа пратиле су романтичне епизоде у којима су централни ликови управо женски. То су, како смо већ навели, Крунослава, Соколица и Сунчаница. Сва три лика деле једну заједничку особину, а то је да су плод песникове маште, односно да нису биле познате историји. Крунослава ${ }^{11}$ - храбра ратница и вереница Коревског - измишљени је лик који је Иван Гундулић градио према ликовима из литературе (Вергилије, Енеида; Тасо, Ослобођени Јерусалим). Она је растужена, утонула у мисли и меланхолична као

10 Разлог због ког је Гундулић обрадио савремени догађај из 1621-1622. године (а коначну верзију епа је радио 1638.) јесте тај што је турски султан Осман умро од руку својих поданика и то је свима стварало слутњу о крају Турске царевине (Гундулић 1967: 24).

11 Према речима Злате Бојовић, једино је Крунослава у детаљима имала овлашних додира са стварним ликом жене пољског великаша Самуела Корецког (Бојовић 1995: 79). 
Ерминија, ${ }^{12}$ а горда као Клоринда ${ }^{13}$ из Тасовог Ослобођеног Јерусалима. Од најранијег детињства васпитавана је као будући ратник и тако очврсла попут Камиле из Вергилијеве Енеиде. Соколица је такође измишљен лик. Она је кћи татарског цара Мотора која је заљубљена у Османа II. У пратњи својих ратница учествује у бици код Хоћина. Соколица убија ратнике такође попут Камиле, али и попут Клоринде. Сунчаница је представљена као кћи слепог старца Љубдрага, који је у делу заправо измишљени потомак Ђурђа Бранковића (Гундулић 2001: 182, 208-251). Нису само ови ликови измишљени. Поред њих, измишљени су, већ споменути Љубдраг, али и Бегум и Алипаша.

Друга нит која повезује Крунославу, Соколицу и Сунчаницу јесте та да се ова три женска лика доводе у везу са мушким ликовима који представљају личности познате историји. Крунослава је у епу вереница Коревског (Самуел Корецки) који је био учесник многих борби са Турцима и који је био ожењен ћерком молдавског војводе Јеремије Мохиле. Био је два пута заточен у Цариграду, а први пут се спасао бекством (Гундулић 2001: 182). Соколица је у епу заљубљена у Османа II, који је и историјска личност и јунак истоименог дела. Осман је био син султана Ахмета I. После очеве смрти, 1617. године на престо долази Османов брат Мустафа који је годину дана касније био збачен са престола, а на чело Турака долази управо Осман. Он је 1621. године повео војску на Пољску (Хоћинска битка) (Гундулић 2001: 160). Сунчаница је девојка из околине Смедерева коју Казлар-ага

\footnotetext{
${ }^{12}$ Посебно место у Ослобођеном Јерусалиму Торквата Таса имају пагански женски ликови, чији је циљ да одврате хришћанске јунаке од њихових циљева. Представљене су као слике очаравајућих жена, веома далеке од уобичајених слика витешке традиције. У Клоринди, Армиди и Ерминији, Тасо ствара три лика која се подударају са тадашњим друштвеним представама о жени. Ерминија представља лепоту повучену у саму себе. Њена неоткривена љубав према Такредију дуго се храни успоменама. Њена најдубља жеља јесте потпуно матерински нагон да помогне рањеном јунаку (Ферони 2005: 379).

${ }^{13}$ Клоринда је жена-ратница која има чар у појављивању и нестајању и у немогућности да се прикаже као жена, осим у тренуцима када ишчезава и када нестаје (Ферони 2005: 380).
} 
намерава да одведе у харем. Кроз његове се речи уноси још један део пољске историје у еп. Он, заправо, велича снаге савремених пољских војсковођа Котковића и Радовилског. ${ }^{14}$

Трећа чињеница која повезује ове јунакиње романтичних епизода јесте та да њихове судбине остају неразрешене управо због недостатка четрнаестог и петнаестог певања, те остаје простор да се само наслути какав би расплет био. Специфичност ових епизода је у томе што је све сведено на женске ликове. У ком смислу? Епизоде у којима учествују Крунослава и Соколица имају у својим основама љубавни заплет, али носиоци радње су женски ликови. Прича која је исплетена око Соколице и Османа више је фокусирана на њене подухвате и осећања. Соколица је грађена према лику амазонки ${ }^{15}$ Ослобођеног Јерусалима Торквата Таса. Она је у пратњи дванаест ратница које песник описује на следећи начин:

\author{
Све у руках копја носе, \\ а у очију држе стријеле, \\ вези од злата њих су косе \\ јашу коње јак снијег бијеле. \\ Сабља о пасу, лук низ плећи \\ у многом им виси уресу; \\ по прилици, по одјећи \\ виле од гора видјет све су. \\ (Гундулић 2001: 210).
}

У лику дванаест ратница спојена је изванредна лепота и храброст, међутим најистакнутија је међу њима Соколица. Њен лик је приказан употребом хиперболе. Она је до те мере смела и храбра да само име и лепота указују на то да је жена. (Гундулић 2001: 209). Она

\footnotetext{
14 Котковић је Јан Карол Ходкјевич, а Радиловски је Алберт Станислав Рађивил. (Бојовић 1995: 30).

15 Наведено је у раду да је Соколица грађена према лику Камиле из Вергилијеве Енеиде и према лику Клоринде из Тасовог Ослобођеног Јерусалима.
} 
је обузета љубављу према Осману те уместо њега излази прерушена на мегдан Крунослави. Њена изванредна неустрашивост приказана је у стиховима:

\author{
По планинама, прико гора \\ врле звијери тражи и диза, \\ и слободна без умора \\ и тјера их и достиза. \\ (Гундулић 2001: 209)
}

Ово, свакако, подсећа на величање јунака у народним епским песмама, где се кроз употребу низа стилских елемената, посебно управо хиперболе, постиже такав ефекат. Соколица више цени слободу од живота, као амазонка лута Пољском како би се осветила за турски пораз, заробљава варшавске госпође и бива заробљена са својих дванаест ратница, а својим јунаштвом добија опроштај од пољског Краљевића Владислава и одлази у Цариград на Османов позив (Бојовић 1995: 54). И премда је описана као ратница која носи кацигу уместо венца на глави, којој је „штит зрцало“ а „витешка оклопја цвит ки носи“, иза тако грађеног женског лика стоји љубав према Осману као мотив за све њене подухвате. У том смислу Соколица има сличности са Крунославом.

Сличност која повезује ове две јунакиње је љубав која их покреће на акцију. Соколица је, како смо навели, заљубљена у Османа, а Крунослава у Коревског. Оба ова женска лика грађена су према ликовима из литературе. Крунослава је грађена према ликовима из Вергилијеве Енеиде и Тасовог Ослобођеног Јерусалима. Затим, обе су представљене као храбре ратнице. И Крунослава је описана на сличан начин:

\footnotetext{
Кад он кћерцу ову стече, покли тада ш ње порода смрт оплака љуби своје за колијевку штит јој пода,
} 
а оклопја за повоје. ${ }^{16}$

(Гундулић, 2001:215)

Крунослава је заљубљена у вереника Коревског који је затворен у цариградској тамници. Да би се осветила, она позива Османа на двобој. Њена је улога сложенија самим тим што писац прати и њен одлазак у Цариград са циљем да Коревског ослободи из тамнице, и ситуацију у којој је она преобучена у Угричића како би дошла до Коревског. Када, уз велики ризик долази, чувару затвора Ризван-паши, и сазнаје да је вереник изневерио, и она доспева у тамницу (Бојовић 1995: 54). У Осману Ивана Гундулића, обе епизоде се прекидају када Соколица и Крунослава треба да се сретну са Османом и Коревским.

За разлику од епизода у којима су јунакиње Соколица и Крунослава, епизода о Сунчаници се разликује. Сунчаница није ратница и, за разлику од претходних јунакиња, заветовала се на чедност. Она живи са оцем Љубдрагом, коме је песник приписао порекло Бранковића и који је изгубио дванаест синова. Сам опис ове јунакиње у супротности је са описима врлих ратница:

\footnotetext{
Чисти златни прам од коси на вјетриц је тих расплела, а од разлика цвитја носи вјенчац врху ведра чела. (Гундулић 2001:237)
}

\footnotetext{
${ }^{16}$ Иван Гундулић је од Торквата Таса преузео концепцију ликова хероина, храбрих, оданих одважних ратница, уплетених у смеле авантуре. Према речима Злате Бојовић, Гундулић је преузео бројне појединости од Таса, а то je, најпре, мотив о детету (у овом случају реч је о Крунослави) које родитељи још од рођења припремају за улогу будуће ратнице. Штитом му се замењује повој, уместо успаванке успављује га бојна труба итд. Опис мегдана између прерушених ратница и тренутака кад им се откривају лица дат је према одговарајућем месту из Ослобођеног Јерусалима.
} 
У овој епизоди, песник опева трагедију оца Љубдрага. Он је измишљени лик, и наводно води порекло од Ђурђа Бранковића, који је изгубио дванаест синова и остала му је, као једина утеха, кћи Сунчаница. Међутим, Сунчаница, девојка изузетне лепоте, зарекла се на чедност а отац јој, у нади да ће се у њој пробудити жеља за љубављу, приређује весеље. Казлар-ага, чувши за њену лепоту, намерава да је одведе у харем. И заиста, са забаве коју јој је отац приредио, хадум одводи Сунчаницу не обраћајући пажњу на очеву жалост и њену тугу. Овде се завршава певање а читаоци даље не сазнају судбину ових јунакиња. Претпоставља се да би судбине биле разрешене у певањима која недостају. О Соколици не сазнајемо још много тога након оног дела када, на Османов позив, креће у Цариград. Судбина Крунославе је, у ово епу, „разрешена“ у затвору када је Ризван-паша затвара на превару. О Сунчаници не сазнајемо ништа више од момента када се нашла код Казлар-аге.

Допуне Османа нудиле су различита разрешења догађаја. Споменуто је да три песника нуде решења повољна за све три јунакиње. Према њима, Соколица постаје Османова жена, Крунослава и Коревски, одредбом мира, бивају пуштени из тамнице, а Сунчаницу султан враћа оцу. У четрнаестом и петнаестом певању Ивана Мажуранића, нема подударања са допунама претходних песника.

У четрнаестом певању разрешена је судбина Крунославе и Коревског. Њихов крај је трагичан. У односу на певања која нуде срећан крај, у допуни Ивана Мажуранића и Коревски и Крунослава губе живот. Коревски је у тамници, а песник придаје пажњу опису и тамнице и јунака:

Ту штипавци гмижу и љуте зми'е по гнусној плију води и’ да засја зрак у куте, богзна од гада што се плоди.

[...]

Лош је у лицу, и пропала вири из дупља сви'ећа од очи, а на прсти'ех попут рала острљат' се нокат кочи. (Гундулић 1990: 239-240) 
На крају четрнаестог певања Крунослава се бори са турском четом која их напада. У тој борби Крунослава бива веома успешна, па песник наводи чак и имена оних које је побила, међутим, бег Сулиман крадом овом пару окончава животе:

$$
\begin{gathered}
\text { Одкли најпри’е Коревског. } \\
\text { Заточеници лијепу пака } \\
\text { згоди зрном шупља из свога } \\
\text { гвоздја њега рука опака. }
\end{gathered}
$$

(Гундулић 2001: 246)

Ни судбина Соколице нема срећно разрешење. У односу на споменуте допуне у којима Соколица постаје Османова жена, у петнаестом певању Ивана Мажуранића Соколица доспева у султанов харем.

Сунчаници је судбина срећно разрешена у сва четири случаја. У Мажуранићевој допуни она јадикује на путу за Дринопоље за својим оцем, али и због своје судбине јер је предодређена да буде турска љуба. То њено јадиковање чуо је хадум који је отео од Казлараге. У лику наводног хадума крио се Влатко, један од давно изгубљене Сунчаницине браће.

Поред ових епизода, интересантна је и она о лепој Аџамкињи Бегум и везиру Дилаверу, који њену слику носи на прсима. Дилавер је њу добио у двобоју са сином персијског краља Хајдером, а њихов однос је затим прерастао у љубав која је прекинута Дилаверовим убиством. У четвртом певању персијанка Бегум носи име Славојка Аџамкиња. И она је, као и претходне јунакиње, измишљени женски лик и то је оно што их све повезује. Поред тога, повезује их и лепота. Дилавер је веома заљубљен у њу, те је у стиховима она божанство коме се он клања. Иако је ова епизода имала елементе типичне за романтичне епизоде у ондашњим еповима, Иван Гундулић је ипак није шире развио( Бојовић 1995: 57). 
Поред ових женских ликова ${ }^{17}$ који су углавном грађени према Вергилијевој Енеиди и Тасовом Ослобођеном Јерусалиму и које су идеализоване и по лепоти и по храбрости, у Осману је, у мањој мери, посвећена пажња и оним женским ликовима који су били познати историји. Највећу пажњу међу њима привлачи Мустафина мајка, чији је лик грађен према утицају Торквата Таса. Док су претходни женски ликови приказани више као елементи романтичних епизода, лик Мустафине мајке се издваја као изграђени карактер. Она је историји позната као мајка Османовог стрица Мустафе која је два пута помогла сину да дође на власт. Такође је познато да је помоћу сплетки остваривала и своје властољубиве жеље (Гундулић 2001: 173) Користећи се историјским чињеницама али и песничким узорима, песник је Мустафину мајку приказао као вештицу. Песник прати њен лик од момента када Осман одузима престо њеном сину, што она доживљава као личну несрећу јер губи утицај који је имала. Она је све оно што претходне јунакиње нису - спремна је на све позивајући у помоћ паклене силе, води порекло из Ердеља, мајка јој је била вештица, уништава све око себе и није лепа, неверна је и спремна је на то да подави Османову браћу како би постала царица. Песник се у описивању Мустафине мајке служи тоном усменог народног приповедања, те се у стиховима често налазе изрази „глас је“ , ,ријеч је“, ,веле“ ... У епу је споменута на два места, а њена улога имала је важне и кобне последице. Она буди мржњу у своме зету Дауту према Осману, убеђујући га да је Осману најближи Дилавер (који некада Дауту није био ни достојан коњушар), а затим га позива на освету. Циљ јој је, наравно, да свргне Османа. Након што је заслепела мржњом Даута, Мустафина мајка се више не спомиње. С обзиром на чињеницу да су ликови Соколице, Крунославе и Сунчанице остали недовршени, лик Мустафине мајке је најцеловитији и најкомплетнији женски лик у епу. Сви њени потези су мотивисани, а она сама приказана је као негација свих позитивних особина које поседују друге јунакиње. Песник чак истиче и њену

\footnotetext{
${ }^{17}$ Међу женским ликовима спомињу се и Љубица и Калинка које су несрећно заљубљене.
} 
спољашњост стихом: „Није лијепа; ну хитрости/ зна с којом се вид заслијепи“ (Гундулић 2001: 175).

Поред ове историјске личности у делу се спомињу и Ана (мајка краљевића Владислава) како би се указало на Владислављево порекло, Цецилија Рената (кћер Фердинанда II, којом се Владислав оженио тек 1637. године), Клеопатра (египатска краљица из 1. века пре нове ере), Јерина (жена деспота Ђурђа Бранковића), Мара (кћер кнеза Лазара и жена Вука Бранковића), Мара (кћер Ђурђа Бранковића и Јерине која је била у харему султана Мурата II). Овим женским ликовима посвећен је по један или пар стихова, а сврха је, углавном, реминисценција на неки историјски догађај. Много је више пажње посвећено оним женским ликовима које су јунакиње романтичних епизода у епу.

Попут свог узора, Иван Гундулић је у Осману измешао свет реалних историјских личности са светом ликова из сопствене маште. Такође, распоред историјских и романтичних елемената сличан је Тасовом - у почетним и завршним певањима они су историјски, а у средишњим су углавном романтични. У „Поетици Гундулићевог Османа“ Мирослав Пантић указује на директне претке и узоре јунакиња. Соколица је страствена као Армида, Крунослава је растужена и меланхолична као Ерминија, а јадиковање ојађене Бегум над мртвим Дилавером има сродности са јадиковањем очајне Тасове Ерминије над мртвим Танкредом (Гундулић 1967: 34).

Женски ликови су, како смо видели, уведени преко романтичних епизода у радњу епа. Стварани су према конвенционалном шаблону а њихови описи одговарају стандардном опису женске лепоте у поезији тога времена са доста барокне претераности (Бојовић 1995:80). Поред изванредног познавања барокне поетике и епског стваралаштва италијанских узора, пре свих Торквата Таса, Џиво Гундулић је познавао и платонистичко поимање лепоте те је тај концепт заступао приказујући своје главне јунакиње романтичних епизода које, свака на свој начин, представљају идеал. Иако су све (овде изузимамо лик Мустафине мајке) носиоци врлина без обзира на то којој страни припадају, највише простора посвећено је Соколици и Крунослави. Сви женски ликови о којима је до сада 
било говора у сенци су главних јунака и главних збивања у епу. Но и поред тога, ови ликови имају и те какав значај у епу и посебну улогу у романтичним епизодама које ово дело сигурно чине и занимљивијим и сложенијим.

\section{ЛИТЕРАТУРА}

Бојовић, Злата. 1995. Осман Џива Гундулића. Београд: Завод за уџбенике и наставна средства.

Бојовић, Злата. 1998. Кюижевност Дубровника - ренесанса и барок. Београд: Филолошки факултет/ Крагујевац: Кораци.

Бојовић, Злата. 2014. Историја дубровачке књижевности. Београд: Српска књижевна задруга.

Гундулић, Иван. 1990. Осман (приредио Бранко Летић). Сарајево: Свјетлост.

Гундулић, Иван. 2001. Осман (приредила Злата Бојовић). Београд: Завод за уџбенике и наставна средства.

Гундулић, Џиво. 1967. Осман (приредио Мирослав Пантић). Београд: Српска књижевна задруга.

Живанчевић. Милорад. 1961. Рукопис Мажуранићеве допуне „Османа". Годишъак Филозофског факултета у Новом Саду 6: 250-266.

Ферони, Ђулио. 2005. Историја италијанске књижевности,Подгорица: CID.

Ljljana Nikić

FEMALE CHARACTERS IN OSMAN BY DŽIVO GUNDULIĆ AND THEIR FATE IN SUPPLEMENT BY MAŽURANIĆ

\section{Summary}

This paper analyzes the female characters in Osman by Ivan Gundulić focusing on those heroines who are the bearers of action in romantic episodes, as well as on the heroines who are only mentioned in the book, but both of which are well-known historically. Special attention was paid to the addition by Ivan Mažuranić and the $14^{\text {th }}$ and $15^{\text {th }}$ verse. The aim of this paper, using the comparative method and critical-interpretative analysis, is to highlight the interconnectedness and the similarity between the heroines of romantic episodes, stressing the importance of 
the other female characters, but also the importance of Mažuranić's addition in showing their fate.

Kew words: Gundulić, Osman, Mažuranić, female characters. 